\title{
Literary History in Canada: The Nation and Identity Formation ${ }^{1}$
}

\section{E.D. B L O D GET T}

New histories that suggest how various traditions can be interwoven and cross-examined would restore the dialectical tension to the dialogical that gets lost in celebrations of liberal pluralism.

Brook Thomas

Whatever else may be the object of its intent, literary history is an argument. It seeks either to construct or rewrite the sense of a nation. In this respect, it participates in a number of discursive practices employed by historians, political scientists, and economists, among others, untroubled by the charges that many critics and theorists of literature have mounted against it during the twentieth century. As critics have repeatedly asserted, literary history cannot "grasp texts as aesthetic designs" (Perkins 7). From the perspective of theory, "literary histories [are], at best, merely hypothetical representations" (Perkins 14). Between the extremes of theory and criticism, however, literary history continues to be written. This is largely because literary history is neither criticism nor theory, but it avails itself sufficiently of both to seem as if it were on occasion, giving the appearance, therefore, of being a dilettante at times in a profession that requires that it show itself as "intellectually responsible" (12).

Inasmuch as its responsibility is for the most part the construction of the nation, literary history only draws upon criticism and theory to serve such an end. True enough, there are literary histories in Canada that appear more encyclopaedic than narrative, such as Carl F. Klinck's Literary History of Canada. Canadian Literature in English, particularly the fourth volume, but most have a nation and a sense of history at least implicitly in mind. In Canada, furthermore, they range from prefatory statements that serve as introductions to anthologies, such as those of A.J.M. Smith, to more monumental statements, such as the on-going Vie littéraire du Québec, already in its fourth volume. Of the sixty-some narratives that constitute the corpus of literary history in Canada, the nation and how it is constituted by means of literary texts is the 
dominant theme. It should be remarked, however, that "nation" is not a term that possesses a definition that would claim general agreement. Nevertheless, it is evident that there are four or five general categories of histories that permit general distinctions to be made. The object of this paper is to examine four contemporary histories, particularly in respect to the manner in which the nation is constructed, and then to situate this discussion in the larger one raised by historians with regard to the construction of nationhood. The histories chosen are in many respects representative and indicate in exemplary fashion the various connotations that "nation" acquires in Canada as it has emerged from ethnic minority, anglophone, francophone, and First Nations traditions.

Three literary histories addressing the problematics of literatures in diaspora have been published, all of which follow a similar pattern of emplotment in order to define both a sense of a nation and to construct a field of identity. I have chosen the first of these, namely, M.L. Mandryka's History of Ukrainian Literature in Canada. ${ }^{2}$ The title already suggests the sense of a nation, for this is not only a history of Ukrainian-Canadian literature but also one of a national literature transplanted, and so it implicitly anticipates an issue raised by Edward Mozejko. As the latter argues, it is not always clear whether the literature of immigrants belongs to the host nation or to their former nation (810). Ukrainian literature begins in Ukraine or, to be more precise, Kievan "Rus," implying that Ukrainian literature in Canada belongs to two national literatures, but possesses a "weak" relationship with both systems. Kievan Rus is constructed as an idyllic moment, however, before Ukraine, after some two centuries of relative peace, was plunged into incessant wars with its neighbours. It is, in Perkins's model, an example of Rise and Fall (Perkins 39), and its recovery, at least in this history, is its eventual resumption in Canada. Needless to say, Ukraine's most recent threat was the Soviet Union, a nation which stands at the end of a series of enemies that endangered the emergence of the nation. The continuation of Ukrainian literature in Canada is constructed as an act of national preservation, and the function of its literary history is primarily commemorative, providing the lineage of heroes serving the nation in literature.

The canon, then, is a martyrology, in the sense that writers are chosen to bear witness to domination under the czars and the Soviets. Ukrainian literature in Canada begins with the work of Semen Kovbel (1877-1966), and his role as inaugurator lies in the distinction Mandryka draws between his writing and folklore. Kovbel's writing is privileged because he strove to overcome nostalgia and the mere retrospection of folklore, becoming "[Ukraine's] free voice before the world" (33). Such a beginning distinguishes Mandryka's history from the Soviet stance, which consistently drew upon folklore as a principle of identity. Kovbel represents, then, the animating ideology of Mandryka's history. He also 
constructs a new identity based upon themes of patriotism and "the Ukrainian struggle for independence" (51).

Such a struggle, however, can only be conducted by those who neither manifest leftist tendencies nor espouse modernist aesthetics. Thus, Vera Lysenko (1910-1975), known, for example, for her The Men in Sheepskin Coats (1947) is disposed of because " $\mathrm{t}$ ] he obvious pro-communist tendencies deprive this book of objectivity" (58). Yar Slavutych (1918-), among others, is hailed primarily because he knew how to avoid the abstractions of the modern: "[b]elonging to the 'new' generation of poets, now in their majority in Europe and the New World plunged in a muddy world of illogical nothingness, in which a poet looks like a lunatic, and not a bard of humanity, Slavutych has saved his poetical integrity and taken a firm stand on the great poetic road" (167-68). Borys Oleksandriv's (1921-1979) poetry is also praised for never swerving "into the treacherous nihilistic camp of a new fashion," and Larysa Murovych (1917-) is deemed akin to Emily Dickinson, inasmuch as both worshiped "Beauty and Right" $(181,185)$. Needless to say, Dickinson did not dwell exclusively in beauty and rectitude, and strong readings of her work, those, say, of Oleh Zujewskyj (1920-1996), one of the greatest of the Modernists in the Ukrainian diaspora, reflect other, more difficult aspects of her work. ${ }^{3}$

Greatness, however, is assigned to Illia Kyriak (1889-1955) and the Ukrainian Catholic priest, Semen Semchuk (1899-1984). The former's novel, Syny Zemli (1939-1945; translated as Sons of the Soil), is praised for its account "of the process of settlement of Ukrainian pioneers, their social, spiritual and cultural organization, their step-by-step integration into the Canadian system, and finally the achievement of remarkable success and stability without losing their identity and cultural heritage" (72). Its realism allows favourable comparison with War and Peace, at least on the level of talent, and it is implied that Kyriak's achievement is all the more admirable, inasmuch as he had none of the material advantages of his predecessor. Semchuk's poetry and short stories are particularly singled out for their moral and spiritual vigour, and the stand they take against the "pessimism and negation of present-day moral looseness" (94).

Mandryka's history, then, inscribes a moral, political, and aesthetic centre whose purpose is to emphasize the struggle for, and preservation of, Ukrainian liberty, which, at the time of writing at least, could only occur in the diaspora. Deviations to the political left or into aesthetic concerns which are deemed nihilistic, that is, which undermine the coherence of the nation, are not constructed as a dynamic activity within the literary system. They are excluded, as they do not belong to the "force-mobile" (45) of Ukrainian culture. In the same way, anything that opposes it is treated as non-Ukrainian and therefore valorized in a negative fashion. Interaction is not permitted, and the Other is not granted a causal status, impelling certain changes in the internal development 
of the literature. For this reason, "the history of Ukrainian literature in Canada cannot be written on the basis of chronological stages." Rather, "[i]ts history is a logical process" (240).

History does not proceed, then, from its inauguration in Kovbel, but from an ideological centre. Literature, furthermore, does not so much grow in time, but transcends it and carries within itself as a "force-mobile" "the immortal Promethean idea of liberation of man and peoples from bondage, of elevating them to spiritual perfection" (239). Growth and elevation from a central core belong to a semiotic field that recalls Herder's idea of history as a harmonious order that turns upon a Synecdochic centre whose aspirations are Comic (cf. White 70-79). Mandryka's nation, like all nations constructed by ethnic minority literatures, can only exist in an ideological imaginary, and depends also upon nineteenth-century notions of ethnic exclusivity and difference. It carries all the weight of the local in space and time (the ideology of Ukrainian nationalism in the years after World War I in its reaction to Soviet occupation), which it has endeavoured to transplant to Canada. The identity-formation that follows upon it, however, cannot carry a future, which would explain why the contemporary generation has put it aside (Balan 752). The emplotment, however, anticipates those used for other ethnic minority and Aboriginal histories, namely, those that follow a pattern of Rise-Fall-Recovery (pace Perkins 37), so long as the final term is understood as one that constructs the contemporary as an operation that at once salvages what appears to be the best of the past and strives to defend itself in the face of various kinds of threats that would abolish its identity.

As we have remarked, the only space of Ukrainian literature in Canada is in the ideological imaginary. The dominant in anglophone literary history, not to speak of much of its literature, is the ambivalent genius loci. As Northrop Frye, echoing others, has remarked, Canada's geographical space is "an obstacle" (824). Its lack of centre reminds one of Gertrude Stein's comment about Oakland, California, namely, "there's no there there." Space, furthermore, is such a dominant that literary historians of English Canada have frequent difficulty in constructing a history that is more than a kind of background against which texts are placed as if they were pictures at an exhibition. A notable example of such a history is Elizabeth Waterston's Survey: A Short History of Canadian Literature, and it is omnipresent and well exemplified in the opening sentences of William J. Keith's Canadian Literature in English: "Canada. A country stretching over 3,00o miles" (Keith 1). Fully aware of the impossibility of finding a centre for Canada, W. H. New's A History of Canadian Literature (1989) begins by arguing against the usual markers of "Snow, North, Wilderness" (New 1) in order to construct a Canada in which "definitions of a single Canadian identity are suspect" (2). For the old conundrum of space, New appears to posit cultural diversity. His next move, as the chapter titles indicate, is to define internal 
difference as a matter of style. Thus, the initial stylistic marker of Canada is myth. These are the myths that belong both to several First Nations that composed Canadian space before European contact and the myths that were made of them by Europeans. Beginning in myth has a distinct impact upon the construction of history inasmuch as it begins in illo tempore, in other words, not in historical but sacred time. Historical time begins with the second chapter in the year 1867, and everything that happened before is drawn into the general theme that Canada is the creation of several nations beginning with "the putative visits to North America by Chinese sailors" (24). It is also the date that permits a distinction between "two political planes: one observing writers sequentially against a set of events, the other observing written works as formal embodiments of separate attitudes and expectations" (24). In most respects, New's preference is for the latter. Sets of events are provided in an introductory manner for every chapter, and so give the impression of points of departure, rather than instruments that would integrate literature and history. When history arrives in the place of myth, it arrives, as the initial sub-heading of the chapter states, as "Background." In this respect, he appears to imply Yurij Tynjanov's notion of literary evolution as immanent change.

The consequence of such an ordering principle is that, as history of literature is constructed as a history of discursive practices, so history itself is understood as a matter of narration. Thus, the second marker is journalism and the reportage of missionaries and explorers. Thus space is made accessible, for the most part in prose, for, as New argues in respect of Jacques Cartier, the founding gesture in the acquisition of space is to give "names to the land" (39). But far from being merely lexicographers, the role of the earlier explorers transcends documentary to narration and in the process becomes part of "the growing signs of shared memories inside Canada, and of memories shared through the art of literary allusion" (46). Narrative practices themselves are thus used to construct the sense of an emerging nation, and at the same time such practices are understood as ideological encoding. Statements by literary historians, furthermore, are subject to the same limitation of horizon, and one of the earliest of English Canada's literary historians, notably Edward Hartley Dewart, is noted as constrained by "his Methodist anglophone Ontario perspective" (8o).

The fourth chapter, "Narrators: Literature to 1959," is the one chapter that addresses the question of the nation, embraced by the years 1922-1959, and the shape of the chapter suggests that the nation came upon the threshold in the final year as part of what are called "National presumptions" and "Sources of change." Both the francophone and anglophone aspirations are carefully weighed, and the chapter concludes with the assertion that: "Writers began to seek structures of expression that would rephrase and so reinterpret their 
culture, free it from the definitions of the 'Other', so to speak, and hence encode a new authenticity of self" (212). In effect the nation cedes almost immediately to the subject as encoder, to use the defining word of the last chapter, which concludes with two significant themes. The first addresses all the narrative strategies used to structure the argument of New's history: "The mythmakers, journalists and storytellers who preceded [the encoders] became consciously part of the context within which they wrote. ... Contemporary writers have reinterpreted their literary inheritance in their own terms, for their own time. They have shaped the words of speech and history into the malleable forms of a contemporary art" (296).

Consistent with the general argument of the book, history of literature may be understood as a plurality of discourses that subsume history and the nation as encoded ideology. More striking, however, is the opening sentence of the paragraph that follows: "The tendency toward fracture, discontinuity, uncertainty and disorder that characterizes so much writing of the 1970 and 1980 os is therefore not fixed" (296). Hence, New summarizes his history by remarking: "Given the context of the closing chapter... it is well to regard this entire book as a history-in-process" (296). Thus, a historicist view of history redeems anglophone writing from the burden of history, a point to which I shall return. It is the final effort among many to achieve this end in English Canada, and it helps explain, perhaps, why it is so difficult for anglophone literary historians to find the nation within their narratives. In this instance, the nation is simply a moment that has passed, that is, if it ever got beyond certain "presumptions," to use New's word. For the nation is not what is desired by the text. What is desired is the realization of discontinuity as, paradoxically, Synecdoche, that is, an integrative structure (cf. White 35) signified by a plot initiated by the mutual misprision of Aboriginal and European and reaching fulfilment in the fissures of discursive practice. If an idea of nation is to survive the challenge of multiple contexts, it is not clear how, inasmuch as the multicultural society espoused by the text is at odds with what New constructs as the more unified society of Québec, another nation in itself, not to speak of burgeoning Aboriginal nations. Or, it means that the idea of nation that literary history struggles with has not yet been fully invented as an articulated entity. More disturbing, however, is the fact that whether or not history is overcome in New, his text represents the culmination of the problem of writing English and French Canada, as well as ethnic minority, Aboriginal, and Inuit cultures, into the same mentality. Adjacent though they may be geographically, they do not appear to know each other, to encounter each other, in any significant way even when they, as in New, accept the framework of history. For histories as articulated through various literatures differ in both use and function, and 
appear capable at best of carrying all the cultures "madly off in all directions," as one might say.

Literary histories of Aboriginal writing in Canada differ radically, as one might surmise, from those of settler histories. They do not feel the need to problematize either space or time - essential issues in anglophone and francophone histories - but rather the catastrophe that European invasion carries with it. There are three such histories, two of which announce in their subtitles how the central issue is to be construed. Penny Petrone's history, which I will discuss here, is entitled, Native Literature in Canada: From the Oral Tradition to the Present. Diane Boudreau's title is somewhat similar: Histoire de la littérature amérindienne au Québec: oralité et littérature. ${ }^{4}$ With more emphasis than Boudreau, Petrone wants to suggest that orality is the mark of the past, and her history is structured to argue that history and writing among First Nations are coterminous. Her first chapter is entitled "Oral Literatures" and her second "1820-1850." Prior to this period, native texts were recorded in English or French primarily by missionaries. It was both native and appropriated. After 1812 and the failure of Tecumseh's efforts to organize a confederacy, native writers began to record their experiences directly without recourse to mythology. Entering history was, needless to say, culturally overwhelming and is analogous to a Fall, in a manner recalling New's narrative, from the world in illo tempore - from the sacred space of myth - into a European sense of time.

Such a historical structure may be attributed to the fact that Petrone is not herself Aboriginal, but simply to compose such literature in a historical framework poses a problem since the pre-contact period is construed as myth. While Petrone does not address this issue, support for doing so may be drawn in part, at least, from the fact that writing was imported as an aspect of missionary work, and the first native texts reflect the influence of the Bible, particularly in the translations of books of the Old and New Testaments by native missionaries into Ojibway. Another genre in which the biblical intertext and paradigm is present is the sermon literature of the period. The languages that eventually predominated were not the native vernaculars, but rather dominant languages of settler-cultures. The paradox that writing in English and French produced, however, was to memorialize catastrophe along with traces of a pre-catastrophic past. It became the sign of dispossession among the many First Nation cultures of Canada, and a primary means for a people in a dominated position to seek agency by providing a lingua franca. Consequently, no history of First Nations writing, no matter how objective it may strive to be, can avoid being political. It is, explicitly or implicitly, a literature of protest, inasmuch as " $\mathrm{t}]$ he literature of Canada's native peoples has always been quintessentially political, addressing their persecutions and betrayals and summoning their resources for resistance" (182). Finally, as I shall indicate in my conclusion, the combination of the 
biblical model and the emergence of a written literature, despite their European provenance, were of deep significance in the ideological emergence of the sense of nationhood.

The writing of history has always been in some sense progressive: one dynasty always follows another. Such a structure, however, does not prevent recursive gestures that inscribe the past with meanings derived from the present of the writer, and in so doing recognize a debt to Nietzsche. In anglophone literary history this tendency is obscured by the fact that history is generally constructed as an hors texte, a background that provides an anatomy of datable events not always intimately related to literature. In the instance of Aboriginal histories, dates are less important than the gradual awareness of what writing represents. Since writing, however, is ambiguous as the sign of loss through which agency is sought, the subject it interpellates is generally split between the "whole" subject of orality and the disseminated subject of writing (cf. Ong 74-77). Much of the effort of literature is therefore turned to recapturing the oral, making it hybrid in a postcolonial sense. The subject is drawn into history but seeks to recover the larger meaning of itself that orality represents, a process well illustrated in Thomas King's novel Green Grass, Running Water. Francophone literary history is also constructed with recursive gestures, arguing that history as a memorializing project integrates the past with the present by inscribing it with the desires of the present.

La vie littéraire au Québec is not only a characteristic but also an exemplary illustration of such a project. It is characteristic because of the continuous construction of a historicized subject. It is exemplary because the "set of events," to use New's expression, is not simply homologous to the literary series, but rather is continuously integrated with writing by means of the institutions which are conjoined in Pierre Bourdieu's notion of the champs. Because all literary history produced in Québec has a clearly articulated beginning (unlike the practice in anglophone literary history), a plot is always discernable: in the beginning the French army was defeated $(1,68)$. The date often chosen is the year 1760 , the year in which the French possessions of North America were ceded to the British. The date chosen in this history, however, is 1764 , the year in which the printing press was brought to Québec. The emergence of a national literature depends, therefore, upon the autonomous means to produce it, and its introduction in this history is an event that originates the field within which literature as the sign of the nation is at stake. For the press was, on the one hand, an instrument of the government and the Church, while, on the other hand, it represented the Enlightenment in action. The field is not, then, an order of historical events; it is, rather, layers of ideological interests that continually intersect, beginning in school curricula, moving through the field of production and reception, and including, in the initial volume, the changes that occurred 
in Europe during the seventeenth and eighteenth centuries in respect of the function of literature. The field is the horizon within which history and literature interact.

As a consequence, literary history is concerned with texts primarily to the extent that they are the manifestation of certain infrastructures without which literature would not be produced. Each volume, then, is framed by general examinations of the field that characterizes the period, the general social and economic conditions of the moment, which include kinds of education available, the state of the language, the figures who used it for whatever ideological purpose, and the market in which literature became public. Only after this information is prepared for the reader are the texts of the period considered. One of the effects of such a structure is that progress is made through time but always by returning to the same kinds of considerations. The form is at once linear and cyclical, and its function draws the actual reader ever closer to the implied reader, each supporting the other in the acquisition of agency that the history enacts. Thus, toward the conclusion of the first volume, while addressing the issue of reception, the role of the press is reviewed as the instrument of production which creates, to use the language of communication models, a receiver who, in turn, becomes a subsequent producer. "Ainsi," it is affirmed, "se referme un cercle qui peut se répéter presque indéfiniment" (I, 356). Here lie all the possibilities of the developing field in the metaphor of the circle, announcing the inception of autonomous agency.

To an extent that might surprise an English-Canadian reader, what is at stake in such a history is the subject, and literature is a function of language and its preservation. Furthermore, unlike anglophone literary history - history in its continuous unfolding - francophone literary history is a foreground such that dates mark not only significant shifts in the literary field but also crucial moments in the positioning of the subject in its trajectory toward fulfilment as an autonomous agent. Although the meaning of the plot varies according to the intent of the historians, it always takes as its habitus a condition pointed out almost a century ago by Charles ab der Halden, a Belgian historian of early French-Canadian writing, namely, that "la littérature canadienne est une littérature d'action" (14). The object of the action is the shaping not of a reader but of a subject enjoined to emerge as distinct from both English-Canadian and French culture. As a consequence, the communication model of production and reception, which is used with great ideological finesse, transcends its role as a means of elucidating the conditions of the field and its agents at a given historical moment. It plays an intensely dramatic and didactic role in bestowing a national identity upon the subject.

While it is often supposed that the activities of literary critics are little more than pious homage to the humanist tradition, this is possibly a delusion. 
Adrian Hastings, in his recent series of lectures entitled The Construction of Nationhood: Ethnicity, Religion and Nationalism, argues, in fact, that: "For the development of nationhood from one or more ethnicities, by far the most important and widely present factor is that of an extensively used vernacular literature" (2-3). Moreover, among several other conditions necessary for nations to emerge, he argues that religion - Christianity in particular - has played an inestimable role in such development. These are arguments that have a special force when considered in the light of the literary histories produced in Canada and Québec. It should be evident, first of all, that, as the examples of these histories provide, the nation is intimately related to vernacular literatures and a fortiori the shape that can be given to them. For the shape they assume is predicated upon a notion of a national subject who reciprocally participates in its formation. The subject is shaped, however, by more than simply a common body of texts. What is necessary, as the title La vie littéraire au Québec implies, is the activity of the literary of which texts are only a manifestation. It is an activity that encompasses all the conflicting aspirations of a society, demonstrating with ease that a nation is an idea that transcends the Gross Domestic Product. So, despite all the skepticism that such theorists as David Perkins express, literary histories continue to be written. As I have suggested, however, their value does not lie primarily in what they say about literary texts as texts, but rather in their modelling function. The emphasis that Hastings places on the vernacular calls attention to the specific character of a nation and its literary manifestation, and certainly one of the important aspects of La vie littéraire au Québec is the history of the survival of the French language in Québec. It is the basis without which neither the nation nor its literature would have emerged. By contrast, New takes language for granted, as do other anglophone literary historians. It is assured through the dominance of English in North America. The problem, as a result, is to distinguish the Canadian from the American vernacular, which almost all anglophone literary histories are at pains to do. What is significant among all these histories is that the vernacular generally employed by First Nations is either English or French in such a way that it has acquired a specific tone that distinguishes it from the languages of the dominant ethnic groups. It has also, I would suggest, encouraged an idea of First Nations in the plural because it creates a broader basis of communication among the several nations than would be otherwise possible, considering the differences among Aboriginal languages.

Of somewhat more interest, however, is the role of religion in the formation of the nation. As we have seen in New, religion is primarily a discursive formation. As I shall indicate, however, it played a larger role in the conceptualization of anglophone literary history. Long before the devastations wrought by the residential schools, missionaries were highly prominent among 
First Nations, and their effect is noted in their respective literary histories. $\mathrm{La}$ vie littéraire au Québec is equally attentive to the educational role played by the Church, particularly in the nineteenth century. Hastings proposes a number of ways in which the Christian religion played a formative role in shaping nationhood: "first, sanctifying the starting point; second, the mythologisation and commemoration of great threats to national identity; third, the social role of the clergy; fourth, the production of vernacular literature; fifth, the provision of a biblical model for the nation; sixth, the autocephalous national church; seventh, the discovery of a unique national destiny" (187-88). Admittedly, these are functions that are developed in respect of the mediaeval church, but they continue to be valid in our more secular contexts.

Unquestionably, during the first half of the twentieth-century Québec was nourished by the manuels of Camille Roy, ptre, and his efforts to promote "la vie nationale" through the study of literature (116-19). Through him, the Church was intimately a part of the national and the literary. ${ }^{5}$ To suggest, however, that La vie littéraire, so clearly inspired by Michel Foucault, Pierre Bourdieu, and Jürgen Habermas, has a Christian subtext may seem ironic. Nevertheless, the conditions that Hastings develops may be seen as put to the service of a clearly secular project. Thus in the first two points, that is, "sanctifying the starting point" and "the commemorating of great threats to national identity", are to be seen the way in which the Enlightenment is embodied in the eighteenthcentury writers Fleury Mesplet and Valentin Jautard, whose inspiration was later reflected in the periodicals of Étienne Parent and the foundational history of François-Xavier Garneau. The latter, furthermore, can be said to have devoted his history to memorializing the formation of a national identity and becoming a continuous reference for literature and history. Finally, that the general trajectory of all francophone literary history is "the discovery of a unique national destiny" goes without saying.

As we have seen, anglophone literary history in New, and practically all the others, appears disconnected from history as lived, temporal experience. Part of the reason for this may also be found through reference to the Bible. Its most eloquent explanation may be found in Northrop Frye, whose "Conclusion" to Klinck's Literary History of Canada is a summa of the anglophone position that draws on his predecessors and paves the way for historians such as New. Frye's view is that literature is mythopoeic, and his predilection is for the apocalyptic, while his reading of history is through the New Testament as fulfilment, revelation and, finally, deliverance from temporality and even literary history (cf. Lecker 201). New may be said to replace mythopoesis with discourse practices, which keep the distance between literature and history clear. His subject, in contrast to the subject of francophone literary history, is not 
positioned within the struggles of history, but, rather, appears to construct itself with autonomous freedom, having moved beyond the limits of the nation.

Where the nation is a recurrent theme, that is perhaps most poignant for writers in diaspora. Ethnic communities, at least in the first and second generation, are deeply preoccupied with preserving the nation, if only in what I have called the ideological imaginary. The geographical nation that is strongest in the formation of identity is already in the past and elsewhere, prompting Michael Greenstein to ask: "Frye's question about Canadian identity - where is here? - becomes compounded by a Jewish question - where was there," opening a space between the here and now and the past (12). One of the strategies for preserving the nation is to keep the language alive and to develop a literature in the vernacular. Such a task can be particularly difficult for modern, ethnic minority societies moving into cultures unlike their own. This has been not only true for Ukrainian immigrants, but also for countless others. In the instance of Ukrainians, these were settlers emigrating at a highly volatile moment in their often volatile history. Not only were there a number of churches eager to look after them in the course of the early years of settlement, as Orest T. Martinowych has argued, but also more secular-minded intellectuals had an interest in their destiny. Besides the foyers provided by churches, "reading clubs, socialist circles, drama societies, co-operative stores and national homes" organized for the most part by socialists endeavoured to foster the continued life of the culture (297). These were activities that parallelled those in Bukovina, Galicia and Ruthenia as a "result of constitional changes made in Vienna to preserve the integrity of the Habsburg domains" and prompted the rise of "reading clubs, choirs, drama circles, schools, co-operative stores" (11 and 13). Because of the history of Roman Catholic Latinization and de facto Polonization in Ukraine during the seventeenth century, the only apparent ecclesiastical support for Ukrainian culture, at least for the secular nationalists, came from the Ukrainian Greek Orthodox brotherhood which organized its own church in 1918 (407-08). Significantly, the orthodoxy they represented was understood to have "played a decisive role in the emergence of Ukrainian national consciousness and statehood in the seventeenth century" (410). It is such a consciousness of national identity that forms a large part of the context for Mandryka's history.

It could be argued, however, that the cultivation of a vernacular, Ukrainian literature was ambiguous in its success. It produced a literature that sustained a culture but one whose relationship to the dominant literary system in Canada remains tenuous. Following the model developed by Enoch Padolsky, there are four modes of relating to larger literary systems: integration, assimilation, separation, and marginalization (608). By preserving the vernacular, most of Ukrainian literature in Canada belongs to the latter categories (609). Ethnic minority cultures are faced with profoundly poignant choices when refusing 
acculturation (cf. Bisztray 41 and 43). In many respects, however, given the effort required to preserve a national identity after so many centuries of occupation, it would appear that Ukrainian writers in Canada made the only valid choice.

Although it would be excessive to essentialize the Aboriginal subject in respect of the nation, inasmuch as their literary histories do not assert nationhood as in the foregoing texts, it can be remarked, nevertheless, that sanctifying the origin is inevitable through the use of oral tales. Furthermore, threats to existence are memorialized in various ways. What is evident is that First Nations are both the victims and to a certain extent the beneficiaries of Christian discursive practices. On the basis of Hastings's arguments, which extend to black African cultures, ${ }^{6}$ it would, however, be difficult to argue that the desire for autonomy that the literary histories of First Nations manifest, approaches that of nationhood in either the francophone or anglophone sense. The extension of the vernacular ${ }^{7}$ and a greater consciousness of alterity would seem to be where most national significance lies. One can only conclude that Canada is not only a divided nation, but one whose plural understanding of nationhood marks all of its literary histories as continuously unfulfilled, still aspiring and moving in divergent directions, a situation it has been in since the first European contact. In this respect it is hardly different from most of the nations of the world in which a multiplicity of fields in Bourdieu's sense interact in constant modification.

\section{NOTES}

${ }^{1}$ I wish to express my gratitude to my friends Andrij Hornjatkevych and Srdja Pavlovic for their timely suggestions made in the course of writing this paper.

${ }^{2} \mathrm{~A}$ longer version of my comments on ethnic minority and First Nations writing has already appeared under the title "Canada as an Alternative World."

${ }^{3}$ Zujewskyj's own absence from Mandryka's history is not surprising, inasmuch as his modernist poetics and antipathy to nationalism were so vigorous that Mandryka chose (and I must assume he knew of his work, despite the fact that he did not immigrate to Canada until 1966) to be indifferent. His towering eminence in Ukrainian-Canadian literature is now thoroughly assured (see Tatiana Nazarenko, "To Pass Through on One's Wings: The Poetry of Oleh Zujewksij," as well as George Grabowicz's article, "Ukrainian Poetry" in The New Princeton Encyclopedia of Poetry and Poetics, where he is repositioned in the Ukrainian literary system and considered "[o]utstanding among a range of poets of the middle generation" (1337).

${ }^{4}$ The third by Robin McGrath is entitled Canadian Inuit Literature: The Development of a Tradition.

${ }^{5}$ Despite Roy's immense efforts, it should be noted, however, that "l'Église catholique a historiquement veillé à ses intérêts, aux intérêts religieux, tout en veillant aussi aux intérêts linguistiques, mais secondaires, dans la hiérarchie de ses valeurs" (Lamonde 245). Such a policy of linguistic marginalization was often dependent upon Rome's notion of the universal church.

${ }^{6}$ As he remarks in a summary fashion, the effects of Christianity were largely undermined in the twentieth century (166). 
${ }^{7}$ As Hastings argues, the written vernacular develops the national, the oral, the ethnic (21 et passim).

\section{WORKS CITED}

Balan, Jars. "Some Notes Toward the Writing of the Ukrainian Literary Institution in Canada." Canadian Review of Comparative Literature/Revue canadienne de littérature comparée 16:3-4 (1989): 745-62.

Blodgett, E.D. "Canada as an Alternative World." New Worlds: Discovering and Constructing the Unknown in Anglophone Literature. Schriften der Philosophischen Fakultäten der Universität Augsburg Nr. 59. Eds. Martin Kuester, Gabriele Christ, and Rudolf Beck. Munich: Verlag Ernst Vögel. 35-49.

Bisztray, George. Hungarian-Canadian Literature. Toronto, Buffalo, London: University of Toronto Press, 1987.

Boudreau, Diane. Histoire de la littérature amérindienne au Québec: oralité et littérature. Montréal: Hexagone, 1993.

Frye, Northrop. “Conclusion." Literary History of Canada: Canadian Literature in English. Ed. Carl F. Klinck. Toronto: University of Toronto Press, 1965.

Grabowicz George. "Ukrainian Poetry." The New Princeton Encyclopedia of Poetry and Poetics. Eds. Alex Preminger and T.V.F. Brogan. Princeton: Princeton University Press, 1993.

Greenstein, Michael. Third Solitudes. Tradition and Discontinuity in Jewish Canadian Literature. Kingston, Montreal, London: McGill-Queen's University Press, 1989.

Halden, Charles ab der. Etudes de littérature canadienne française. Paris: Rudeval, 1904.

Hastings, Adrian. The Construction of Nationhood: Ethnicity, Religion and Nationalism. Cambridge: Cambridge University Press, 1997.

Keith, William J. Canadian Literature in English. London and New York: Longman, 1985.

King, Thomas. Green Grass, Running Water. Toronto: HarperCollins, 1994.

Lamonde, Yves. Allégeances et Dépendances. L'Histoire d'une ambivalence identitaire. Québec: Éditions Nota Bene, 2001.

Lecker, Robert. Making It Real: The Canonization of English-Canadian Literature. Concord, Ont: Anansi, 1995.

Lemire, Maurice, ed., et al. La vie littéraire au Québec. Vols. I-II. Saint-Foy: Les Presses de l'Université Laval, 1991-1992.

- and Denis Saint-Jacques, et al. La vie littéraire au Québec. Vols. III-IV. Saint-Foy: Les Presses de l'Université Laval, 1996, 1999.

McGrath, Robin. Canadian Inuit Literature: The Development of a Tradition. National Museum of Man Series/Musée nationale de L'Homme collection Mercure. Canadian Ethnology Service Paper No. 94/Le Service canadien d'Ethnologie dossier No. 94. Ottawa: National Museums of Canada/Musées nationaux du Canada, 1984.

Mandryka, M.L. History of Ukrainian Literature in Canada. Winnipeg and Ottawa: Ukrainian Free Academy of Sciences, 1968.

Martynowych, Orest T. Ukrainians in Canada: The Formative Period, 1891-1924. Edmonton: Canadian Institute of Ukrainian Studies Press, 1991.

Mozejko, Edward. "Ethnic or National: Polish Literature in Canada." Canadian Review of Comparative Literature/Revue canadienne de littérature comparée 16:3-4 (1989): 809-25.

Nazarenko, Tatiana. “To Pass Through on One's Wings: The Poetry of Oleh Zujewksij." Canadian Slavonic Papers/Revue canadiennes des slavistes XXXVII (1996): 23-46.

New, W.H., ed. Literary History of Canada: Canadian Literature in English. Vol. 4. Toronto: University of Toronto Press, 1990

New, W. H. A History of Canadian Literature. London: Macmillian Education Ltd., 1989. 
Ong, Walter J. Orality and Literacy. The Technologizing of the Word. New Accents. London and New York: Methuen, 1982.

Perkins, David. Is Literary History Possible? Baltimore and London: Johns Hopkins University Press, 1992.

Petrone, Penny. Native Literature in Canada: From the Oral Tradition to the Present. Toronto and New York: Oxford University Press, 1990.

Thomas, Brook. The New Historicism and Other Old-Fashioned Topics. Princeton: Princeton University Press, 1991.

Waterston, Elizabeth. Survey: A Short History of Canadian Literature. Toronto: Methuen, 1973.

White, Hayden. Metahistory: The Historical Imagination in Nineteenth-Century Europe. Baltimore and London: Johns Hopkins University Press, 1973. 
